\title{
Effect of Professionalism and Code of Conduct on The Performance Engineer
}

\author{
Khalida Syahputri, Rahmi M.Sari, Anizar \\ Department of Industrial Engineering \\ University of Sumatera Utara \\ Medan, Indonesia \\ syahputri.khalida@gmail.com
}

\begin{abstract}
In an era of global competition, every profession demanded professionalism in the work, as well as the profession of an engineer. An engineer should be able to continue to improve its performance in order to compete in a globalized world. The performance measurement of an engineer is usually seen on the characteristics of its professional attitude. Professionalism of an engineer can not be separated from the code of professional conduct. Codes of ethics are the values, norms, or rules to regulate moral behavior of a profession through written provisions that must be met and adhered to every member of the profession. The code of ethics is what serves as a guideline for all members of the profession on the principle of professionalism in the work. Professionalism and professional code of ethics is closely related to the performance obtained from an engineer. Therefore, this study aims to look at the effect of the code of ethics and professionalism to the performance of an engineer. The method used in this study using statistical methods. Data analysis technique used is linear regression analysis. Based on the results of linear analysis obtained $t$ count is bigger than $t$ table so that it can be concluded that the variables of professionalism and professional codes of conduct have a significant effect on the performance of an engineer. These results show that professionalism and ethical strongly supports improving the performance of an engineer.
\end{abstract}

Keywords: engineer, professionalism, code of professional conduct, performance

\section{INTRODUCTION}

In the globalization era, which began rolling into all corners of the world, advances in technology and information has been growing rapidly. The development should also be in line with the human resource capabilities possessed by each. Globalization has positive and negative effects. From the positive side we can use globalization to view benchmark development in Indonesia, particularly in the field of engineering.

Indonesia is one of the developing countries that play an active role in the globalization era. Indonesia has also been duly prepared in preparing qualified, innovative and creative human resources, including the field of engineering. Because that is also what currently required by Indonesia. Engineer as actors in the field of engineering profession needs to hold tight to the values, morals, and character in running professionalism workplace so that it can perform its functions well. Engineer also have to extensive the capabilities and competitive advantage, so it has high competitiveness in entering the global work environment (elshinta news.com, 2014)

Engineering is a profession that plays an important role in the economic development process. This is particularly an important role in developing the economic infrastructure in the era of industrialization and information. As a professional in their field, an engineer should have the competence and background of the engineering profession. In carrying out his profession and expertise, an engineer will oftenly face a variety of activities that cannot be separated from the conflicts of interest that could obscure the professional values and goals "for the benefit of mankind" that has been formulated. Therefore the role of the code of ethics and professionalism is needed by an engineer. Professional engineers have a personal and professional obligation to society to 
act in an ethical manner. Professional ethics instruction in engineering is commonly conducted by examining case studies in light of the code of conduct of a suitable professional body (Brad Stappenbelt, 2013)

Professional engineers have a personal and professional obligation to society to act in an ethical manner. Professional ethics instruction in engineering is commonly conducted by examining case studies in light of the code of conduct of a suitable professional body (Loui, M.C. (2005). The ethical and moral development study conducted by Loui (2005) revealed that the greatest benefit of professional engineering ethics education is to reinforce students' inclination to act ethically. The instruction on moral reasoning frameworks and professional codes of conduct providing encouragement to act on the personal ethical and moral convictions already held (Buckeridge, J. (2011). Buckeridge argues the importance of ethics training for engineers in light of the significance this is given in the Washington Accord and subsequently in the Institute of Engineers Australia (IEAust) code of conduct.

Therefore, it would need to do a research on the effects of professionalism and professional ethics of an engineer to performance of an engineer in the era of globalization.

\section{MATERIALS AND METHODS}

This study uses regression analysis. Regression analysis is a statistical tool for the investigation of relationships between variables. Usually, the investigator seeks to ascertain the causal effect of one variable upon another, for example the effect of a price increase upon demand, or the effect of changes in the money supply upon the inflation rate. (Astrid, et. 2010)

Regression analysis is a type of statistical evaluation that enables three things:

- Description: Relationships among the dependent variables and the independent variables can be statistically described by means of regression analysis.

- Estimation: The values of the dependent variables can be estimated from the observed values of the independent variables.

- Prognostication: Risk factors that influence the outcome can be identified, and individual prog- noses can be determined. (Deby and Junhong 2010)

In regression analysis, it is known to have two types of variables, namely: the response variable or also called dependent variable. Variables whose existence is influenced by other variables and commonly denoted by Y. Predictor variables and is also called independent variables. Variables that not influenced by other variables and commonly denoted by X. (Ario Wiratmoko, 2012)

Regression analysis is concerned with predicting the mean value of a dependent variable, $Y$ from known values of one or more independent variables Xi (Rita Van der vorst, 2007). The effects of one or more independent variables combine to determine the response variable.

Simple Linear Regression Model equation is as follows:

$Y=a+b X$

Where as,

$\mathrm{Y}=$ the response variable or dependent variable

$\mathrm{X}=$ Variabel Predictor or independent variable

$\mathrm{a}=$ constanta

$\mathrm{b}=$ koefisien regresi (kemiringan); value of

Response that caused by Predictor.

The values of $a$ and $b$ can be calculated by using the formula below:

$$
\begin{aligned}
& \mathrm{a}=\frac{(\Sigma \mathrm{y})\left(\sum \mathrm{x}^{2}\right)-\left(\sum \mathrm{x}\right)\left(\sum \mathrm{xy}\right)}{\mathrm{n}\left(\Sigma \mathrm{x}^{2}\right)-\left(\sum \mathrm{x}\right)^{2}} \\
& \mathrm{~b}=\frac{\mathrm{n}\left(\sum \mathrm{xy}\right)-\left(\sum \mathrm{x}\right)(\Sigma \mathrm{y})}{\mathrm{n}\left(\Sigma \mathrm{x}^{2}\right)-(\Sigma \mathrm{x})^{2}}
\end{aligned}
$$

Criteria for acceptance and rejection of the hypothesis if:

a. $t_{\text {count }}>t_{\text {table }}$ or significance $\leq 0.05$, then the null hypothesis (Ho) is rejected and the alternative hypothesis $(\mathrm{Ha})$ is accepted.

b. $t_{\text {count }} \leq t_{\text {table }}$ or significance of $>0.05$, the null hypothesis (Ho) is received and the alternative hypothesis (Ha) is ejected [8] 
In this article regression analysis is used to view the effect of professionalism and code of conduct on the performance engineer. The dependent variable $(\mathrm{Y})$ used in this study is the performance engineer while the independent variable is the code of conduct and professionalism.

\section{RESULT AND DISCUSSION}

Engineering, those are working on engines. Reviews These words are very provocative "definition" represents the etymological meaning of the word. However, engineering as understood today, IS ALSO the holistic consideration of the application of technology on every problems [9] Engineers is a profession which plays an important role in the implementation of development because of many activities such as design and engineering within the competence of an engineer. Engineering profession requires training and mastery towards a special knowledge. A profession usually has a professional association, code of ethics and the process of certification and licenses to specific areas of the profession. Similarly, the engineering profession, has a professional association of engineers and have a code of ethics of engineers.

As a professional engineer who has sued for working professionals in their field. Professional is a truly skilled in the art, professionalism is a manifestation of an effort that is optimal from a profession to fulfill its obligations in a way that does not harm others, so that actions can be accepted by all related elements. As a professional, engineers must be able to sustain the idealism which states that the professional expertise they commanded is not a mere commodity to be bought and sold for a profit. An engineer must understand the true meaning of professionalism if you want to say a professional. The measurement of performance of an engineer is usually seen on the characteristics of its professional attitude. Professionalism of an engineer cannot be separated from the code of professional conduct.

The word ethics or ethics derived from the word ethos which means character, morals, or customs. As a subject, ethics will be related to the concept of the individual or group to judge whether their actions is false or true. The code of ethics of engineers published by ABET (1985) contain a statement of the four (4) principles of fundamental ethical profession engineering, as follows: Engineer uphold and advance the integrity, honor and dignity of the engineering profession by (a) using Reviews their knowledge and skills for the enhancement of human welfare; (B) being honest and as impartial, and serving with fidelity the public, Reviews their employers and clients; (C) striving to increase of the competence and prestige of the engineering profession and (d) supporting the professional and technical societies of their disciplines (Sritomo W, 2000)

Codes of ethics are the values, norms, or rules to regulate moral behavior of a profession through written provisions must be met and adhered to every member of the profession. The code of ethics is served used as a guideline for all members of the profession on the principle of professionalism in the work.

With their professional code of ethics, there will be some sort of rules that can be used as guidelines to protect the interests of society. Besides, the code of professional conduct itself used to build the "image" and maintain the integrity and reputation of the profession, as well as providing an overview of the inter-relationship between the provider and the user to go service professionalism.

Based on previously described, can be seen the relationship between the attitude of professionalism with the code of professional conduct. Therefore, we will see how the effects of professionalism and professional ethics on the performance of an engineer. It is important to be able to compete in the era of globalization began to roll. The method used to see the relationship between variables was conducted using linear regression analysis. Results of linear regression analysis obtained:

$$
\begin{aligned}
& \mathrm{t}_{\text {count }}=4.805 \text { and } \\
& \mathrm{t}_{\text {table }}=2,042
\end{aligned}
$$

From the results obtained that $t_{\text {count }}>t_{\text {table. }}$. This means Ha is accepted and Ho is rejected so it can be demonstrated a significant difference between the code of professional conduct and professionalism of the performance engineer. 


\section{CONCLUSION}

From the results of regression analysis obtained that $t_{\text {count }}>t$ table, so we can conclude that the variables of professionalism and professional codes of conduct have a significant effect on the performance engineer. These results show that professionalism and ethical strongly supports improving the performance of an engineer.

\section{REFERENCES}

Ario Wiratmoko. (2012). Effect of Robotics Extracurricular Activities Students Against Emotional IntelligencEe, e-journal, Yogyakarta, 2012.

Astrid Schneider, Gerhard Hommel, and Maria Blettner. (2010). Linear Regression Analysis, Part 14 of a Series on Evaluation of Scientific Publications, Deutsches Ärzteblatt International Dtsch Arztebl Int; 107(44): 776-82.

Brad Stappenbelt. (2013). Ethics in Engineering : Student Perceptions and Their Professional Identity Development, Journal of Technology and Science Education http://dx.doi.org/10.3926/jotse.51.

Buckeridge, J. (2011). Do engineers still move mountains?: A "new world" appraisal in light of ethics, engineering, economics and the environment. Australasian Association for Engineering Education Conference2011: Developing engineers for social justice: Community involvement, ethics \& sustainability 5-7 December2011, Fremantle, Western Australia. pp. 7-12.

Debi P. Mishra, Junhong Min. (2010). Analyzing the relationship between dependent and independent variables in marketing: a comparison of multiple regression with path analysis, Journals of business perspective, Innovative Marketing, Volume 6, Issue 3.

elshinta.com/news. (2014). Indonesia Need Innovative and Creative Young Engineer To Face Globalization.

Loui, M.C. (2005). Ethics and the Development of Professional Identities of Engineering Students. Journal of Engineering Education, 94(4), 383-390. http://dx.doi.org/10.1002/j.21689830.2005.tb00866.x

Rita Van der vorst. (2007). Engineering, Ethics and Professionalism, European Journal of Engineering Education. Taylor and Francis, London, April.

Sykes, O. Alan. (1993). An Introduction to Reggression Analysis, The Inaugural Coase Lecture, www.law.uchicago.edu/files/files/20.sykes.

Sritomo Wignjosoebroto. (2000). Professional ethics (engineer): Should proposed to be included in the curriculum of technical schools, /teknologi, Surabaya, 2000. 